From the "Staats Veeartsenijkundig Onderzoekingsinstituut" Amsterdam

(Director: Dr. H. S. Frentel)

\title{
Haemadsorption in Vaccinia-Infected Tube Tissue Cultures
}

\author{
By \\ Jaap H. Driessen* and Leighton W. Greenham** \\ With 5 Figures \\ (Received November 5, 1958)
}

The adsorption of guinea-pig erythrocytes to the cells of monkey kidney tissue cultures infected with influenza virus was shown by Vogel and Shelokov (1) to be a specific reaction. The reaction was found to be inhibited by prior treatment of the infected cultures with anti-influenza sera known to inhibit haemagglutination. All cytopathogenic strains of influenza virus were shown to give a positive reaction, but no such reaction took place in the absence of influenza virus. At that time the authors termed the reaction "adsorption haemagglutination".

At the time of publication of the article, one of us (J. H. D.) was searching for a simple yet reliable test for determinating the immunity response of large numbers of military personnel to smallpox vaccination. It was thought that the "adsorption haemagglutination" reaction might be used in the formulation of such a test. For this reason similar studies were undertaken with vaccinia virus.

When the initial studies with vaccinia virus were nearing completion Shelokov, Vogel and Chi (2) reported an extension of the original studies and showed mumps-, croup-associated-, Sendai-, Newcastle Disease- and vaccinia viruses to give positive reactions in addition to influenza virus. Encephalomyocarditis-, poliomyelitis-, herpes simplex-, coxsackie-, ECHOand adenoviruses were shown to give negative reactions.

They renamed the phenomenon "haemadsorption".

* Capt. M. D. Department of Preventive Medicine R. N. A.

** Animal Health Trust Research Scholar. Present adress: Department of Bacteriology, University of Bristol, England. 
Their studies with vaccinia virus were not as complete as those with influenza virus and the purpose of the present article is to present additional information on the subject of vaccinial haemadsorption.

\section{Materials and Methods}

Tissue culture systems. Stationary tube cultures were used throughout the experiments.

a) Human embryonic kidney (HEK) cultures, strain $\mathrm{N}$, were routinely used in the studies. The cells were kindly supplied by Dr. S. Frenkel of Amsterdam. Stock cultures were maintained in Roux-or similar flasks and tube subcultures prepared from these. Using a Pasteur pipette with curved tip the cells were washed off the surface of the flask with fresh culture medium and the total cell-count of the suspension adjusted to approximately $10^{6}$ cells per $\mathrm{ml}$. Two $\mathrm{ml}$. of the suspension were used to seed each tube and nearly continuous cellayer cultures were formed within $3-4$ days at $37^{\circ} \mathrm{C}$. One hundred $\mathrm{ml}$. of the culture medium consisted of:

$\begin{array}{lr}5 \mathrm{x} \text { concentrated Earle's balanced salt solution } \\ \text { (without } \mathrm{CaCl}^{2} \text { but containing } 0.08 \text { grms. of } \\ \text { phenol red per } 1000 \mathrm{ml} \text { ) } & 18 \mathrm{ml} \text {; } \\ \text { double distilled water } & 43 \mathrm{ml} \text {; } \\ 2.5 \% \text { lactalbumin hydrolysate* } & 20 \mathrm{ml} \text {; } \\ 0.2 \% \text { CaCl } & 9 \mathrm{ml} \text {; } \\ \text { fresh, inactivated horse serum } & 10 \mathrm{ml} \text {; } \\ \text { Penicillin, streptomycin. aureomycin and nystatin** } & \\ \text { were added to control contaminants. }\end{array}$

b) Beef embryonic kidney (BEK) cultures were prepared by trypsinisation of minced kidney cortex (3) employing calcium and magnesium free phosphate buffered saline and trypsin solution for this part of the procedure. The cells were washed in phosphate buffered saline after trypsinisation and resuspended in culture medium to give an $0.5-1 \%$ cell suspension by volume. Tubes were seeded with $2.0 \mathrm{ml}$. of the suspension and nearly continuous cellayers developed in $4-5$ days at $37^{\circ} \mathrm{C}$. The culture medium was that described for HEK cultures.

c) Beef embryonic skin cultures were prepared in a similar fashion to the beef embryonic kidney cultures. Cellayers were obtained in $4-5$ days at $37^{\circ} \mathrm{C}$.

d) Plasma-clot cultures of beef embryonic skin were prepared with fowl plasma. The inner surface of the tubes were coated with a film of plasma in which pieces of minced tissue were placed. After clotting $2.0 \mathrm{ml}$. of culture medium were added to each tube. The culture medium for this system consisted of $10 \%$ horse serum in non toxic beef amniotic fluid with added antibiotics. Extensive fibroblastic proliferation was obtained within 7 days at $37^{\circ} \mathrm{C}$.

Vacoinia Virus. Two strains were employed.

a) One strain was obtained from Dr. $H$. S Frenkel, Amsterdam. This strain had been maintained over a period of four years by passage in bovine embryonic skin cultures (4). The passages $78 ; 133-134$; and $136-137$ were used. It was used either in the form supplied (skin homogenate) or following

* Nutritional Biochemicals Corp., Cleveland Ohio.

** E. R. Squibb \&. Sons, New York. 
one or two passages on the chorioallantoic membrane of embryonated eggs, or on HEK or BEK cultures.

b) The second strain of the virus was obtained from the State Department of Public Health (Rijks Instituut Voor De Volksgezondheid) Utrecht, as Vaccine Iymph (calf lymph).

\section{Other viruses}

Foot and mouth disease virus, types $\mathrm{A}, \mathrm{O}$, and $\mathrm{C}$ were obtained by courtesy of Dr. H. S. Frenkel, Amsterdam.

Adenovirus type 2, ECHO virus type 8, herpes simplex virus and measles virus were all kindly supplied by Dr. F. Dekling, Amsterdam.

\section{Erythrocytes}

Fowl, rabbit, guinea-pig, mouse, calf, sheep and human (A, B, AB and 0 ) erythrocytes were used in the haemadsorption tests. Whole blood, collected with an equal volume of sodium citrate solution $(3.8 \%)$ was stored in at least 5 times its volume of Alsever's solution (5) at $4^{\circ} \mathrm{C}$. Erythrocytes so stored could be used for up to 4 weeks after collection.

Before use the erythrocytes were washed three times in normal saline, with centrifugation at 2000 RPM for 5 mins. between washings to deposit the cells, and resuspended in normal saline to give a $2 \%$ suspension.

\section{Immune Sera}

a) Hyperimmune rabbit serum against vaccinia virus was prepared by a sequence of one cutaneous, two subcutaneous and two intravenous inoculations with vaccinia virus strain b) described above, diluted to $10 \%$ and centrifuged to clarify.

Serum was collected 7 days after the last inoculation and was titrated against vaccinia virus in a haemagglutination-inhibition test before storage at $-20^{\circ} \mathrm{C}$.

b) Human convalescent serum, obtained from military personnel 6 weeks after primary vaccination.

c) $16 \%$ human hyperimmune gamma globulin, prepared from the convalescent serum of soldiers 6 weeks after vaccination, was kindly supplied by Dr. W. Nanning, Lt. Col. M. D.

\section{Haemadsorption Tests}

Vaccinia virus preparations were first titrated on the chorioallantoic membranes of embryonated eggs by inoculation with $0.1 \mathrm{ml}$. of different dilutions of the virus strains, and their titres recorded in pock forming units (PFU) per $\mathrm{ml}$. Tube tissue cultures were drained of culture medium and replenished with $2.0 \mathrm{ml}$. of fresh culture medium, containing known numbers of PFU. Following reincubation at $37^{\circ} \mathrm{C}$ for at least 24 hrs. $0.2 \mathrm{ml}$. of fowl erythrocyte suspension was added to each tube and the tubes further incubated for $15-30$ mins. at $37^{\circ} \mathrm{C}$ to permit full adsorption of the erythrocytes. The tubes were shaken gently to wash all non-adsorbed erythrocytes from the cellayer and "heamadsorption centre" counts made at $100 x$ magnification.

A "haemadsorption centre" was defined as any group of adjacent tissue cells, each of which showed a definite adsorption of fowl erythrocytes.

With viruses not giving a simple haemagglutination with fowl erythrocytes the test was carried out to determine whether or not such centres were formed. 


\section{Neutralisation Tests}

Serial doubling dilutions of immune antivaccinial sera were made in culture medium. To $0.2 \mathrm{ml}$. of each dilution was added $0.2 \mathrm{ml}$. of a vaccinia virus preparation containing in that volume the equivalent number of PFU used in the corresponding haemadsorption test. The mixtures were incubated 45 mins. at $37^{\circ} \mathrm{C}$ and inoculated into tissue cultures together with $1.6 \mathrm{ml}$. of fresh culture medium. The tests were read at the same time and in the same manner as the corresponding haemadsorption tests.

Some incubated mixtures (of virus and antiserum) were inoculated in the chorioallantoic membranes of embryonated eggs, in $0.1 \mathrm{ml}$. amounts. The pocks were counted after 3 days incubation.

\section{Inhibition of Haemadsorption}

Tissue cultures had their medium replaced with $2.0 \mathrm{ml}$. of fresh culture medium containing a sufficient number of vaccinial PFU to give a readable haemadsorption test after $24 \mathrm{hrs}$. incubation at $37^{\circ} \mathrm{C}$. Following incubation for this period the cultures were washed with up to 5 changes of normal saline and $2.0 \mathrm{ml}$. of fresh culture medium, containing either $0.2 \mathrm{ml}$. of immune serum or $0.02 \mathrm{ml}$. of human hyperimmune gamma globulin added to each tube. The cell cultures were further incubated for 60 mins. at $37^{\circ} \mathrm{C}$ and the tests read in the manner of the heamadsorption tests.

\section{Plate Haemagglutination Tests}

These were carried out with vaccinia virus haemagglutinin and the various erythrocyte samples. The haemagglutinin was prepared from infected chorioallantoic membranes, previously inoculated with $0.1 \mathrm{ml}$. of a virus suspension containing large numbers of PFU. After 3 days incubation the membranes were harvested, homogenised, and centrifuged $15 \mathrm{~min}$. at 2000 RPM to clarify. The supernatant was stored at $-20^{\circ} \mathrm{C}$. The amount of haemagglutinin to be used in the haemagglutination inhibition test was estimated from a haemagglutination test. Serial doubling dilutions of haemagglutinin were prepared with $1 \%$ inactivated normal rabbit serum in normal saline in the cups of a "perspex" haemagglutination plate. An equal volume of the serum saline was added to each cup followed by a third volume of a $2 \%$ erythrocyte suspension. The plates were shaken and incubated at $37^{\circ} \mathrm{C}$ until the erythrocytes had settled out.

In the haemagglutination inhibition test immune serum dilutions were substituted for the serum saline (in the same volumes). The concentration used in the haemagglutination inhibition test was that concentration of haemagglutinin which gave a strongly positive haemagglutination by itself and its doubling dilutions, estimated previously from a haemagglutination test.

\section{Results}

\section{The Vaccinial Haemadsorption Test}

The test depends upon the interaction of the 3 separate test materials - the tissue culture system, the strain of virus and the "indicator" erythrocytes - each of which could possibly affect the course of the test. For this reason various combinations of the three were tried to determine the most suitable method for carrying out the test. 
a) The tissue culture system

Each of the 4 tissue culture systems described gave similar results. Positive haemadsorption tests were recorded with each, but counts of haemadsorption centres were possible only with the three systems providing more or less continuous cellayer cultures.

b) The strain of virus

Both strains of vaccinia virus used in the studies gave positive tests.

c) The "indicator" erythrocytes

Fowl erythrocytes were found to be adequate for the requirements of the test. Positive haemadsorption tests were obtained with each of the 46 different samples of fowl erythrocytes tested; 21 of these samples gave a negative plate haemagglutination test.

Of the remaining types of erythrocytes similarly tested only those of the one mouse tested, gave a positive haemadsorption. Rabbit, guineapig, calf, sheep and human erythrocytes gave negative tests. All gave very weakly positive or wholly negative plate haemagglutination tests.

\section{The Specificity of the Vaccinia-Foul Erythrocyte Haemadsorption Test}

The following experimental observations demonstrated the specificity of the test:

a) Haemadsorption of fowl erythrocytes to the cells of vaccinia infected tissue cultures was observed with each of the tissue culture systems used. Non infected control cultures failed to give positive tests.

b) The addition of hyperimmune rabbit serum or human hyperimmune gamma globulin, prepared as described above, to previously infected cultures markedly reduced or prevented the haemadsorption of fowl erythrocytes.

Normal rabbit serum failed to produce such inhibitory effects ('Table 1).

Table 1. Haemadsorption inhibition in HEK cultures

\begin{tabular}{c|c|c|c|c}
\hline \multicolumn{3}{c|}{ Infected cultures } & $\begin{array}{c}\text { Non-infected } \\
\text { control } \\
\text { cultures }\end{array}$ \\
\hline $\begin{array}{c}\text { Hyperimmune } \\
\text { rabbit } \\
\text { serum }\end{array}$ & $\gamma$-globulin & $\begin{array}{c}\text { normal rabbit } \\
\text { serum }\end{array}$ & $\begin{array}{c}\text { physiological } \\
\text { saline }\end{array}$ & - \\
\hline \pm & \pm & +++ & +++ & - \\
\pm & \pm & ++ & +++ & +++ \\
\hline
\end{tabular}

Key: +++ Haemadsorption with $50-100 \%$ of tissue cells.

++ Haemadsorption with $10-50 \%$ of tissue cells.

+ Haemadsorption with $<10 \%$ of tissue cells.

\pm Haemadsorption with $<1 \%$ of tissue cells.

- No haemadsorption. 
c) With the neutralisation test it was possible to demonstrate a reciprocal relationship between the effective serum dilutions and the haemadsorption centre counts (Fig. 1).

d) Non-specific degenerations of tissue cultures, due to such causes

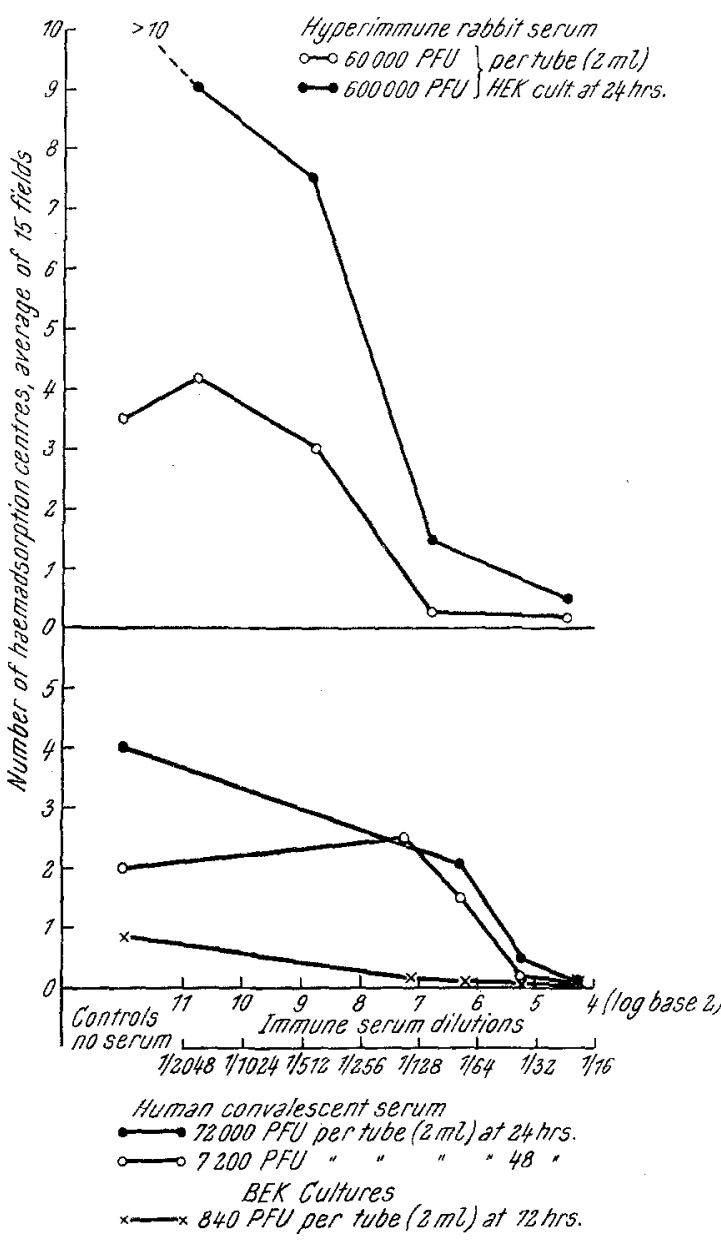

Fig. 1. The haemadsorption neutralisation test The effect of varying dilutions of immune sera upon haemadsorption centre counts at 24,48 and 72 hrs. as low $\mathrm{pH}$ of the culture medium or microbial contamination, failed to exhibit haemadsorption with fowl erythrocytes.

Viruses not capable of haemagglutinating fowl erythrocytes - foot andmouthdisease, adeno type 2, ECHOtype 8, herpes simplex and measles viruses - were found to be incapable of producing haemadsorption.

The Sensitivity of the Vaccinia-Fowl Erythrocyte Haemadsorption Test

a) The effect of variation of inoculum size upon the time of haemadsorption centre formation

The time at which haemadsorption centres were first discernible microscopically was found to be dependent upon the number of PFU in the infecting inoculum (Table 2). The latitude of the test, in this respect, was quite large. A variation of inoculum size between 3000 and 6000 PFU produced centres within $24 \mathrm{hrs}$; between 30 and $600 \mathrm{PFU}$ within $48 \mathrm{hrs}$.

b) The optimum period for incubation following virus inoculation

The number of haemadsorption centres produced in an infected culture increased as the post-inoculation incubation period was prolonged (Fig. 2). 
However, as the size of the virus inoculum governed the time at which haemadsorption centres first became discernible an optimum incubation period could not arbitrarily be stated. It would appear desirable to make the count at a not later than 24 hrs. stage because of the possibility of secondary haemadsorption centre formation.
Table 2. The effect of variation of in oculum size on the time at which haemadsorption centres were first discernible.

\begin{tabular}{c|c}
\hline $\begin{array}{c}\text { No. of PFU's in } \\
\text { inoculum }\end{array}$ & $\begin{array}{c}\text { Time (in hrs.) at which } \\
\text { haemadsorption centres } \\
\text { first discernible. }\end{array}$ \\
\hline $3000-6000$ & 24 \\
$300-600$ & 48 \\
$30-60$ & 48 \\
$3-6$ & 72 \\
\hline
\end{tabular}

c) The number of PFU required for the formation of a single haemadsorption centre

From consideration of Fig. 2 it would appear that a single centre required between $3.0-7.2 \times 10^{3} \mathrm{PFU}$ for its formation within $24 \mathrm{hrs}$.

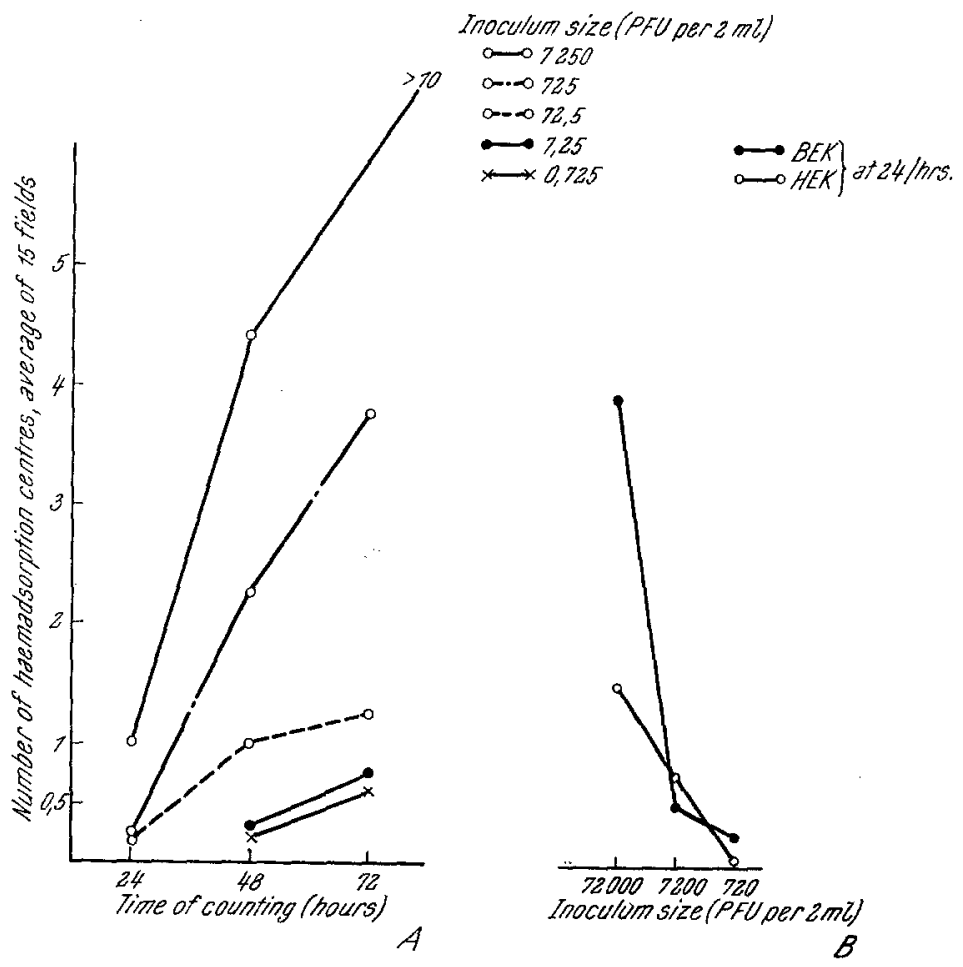

Fig. 2. Haemadsorption centre counts in HEK tissue cultures

A) Effect of varying sizes of inocula and times of counting upon the counts themselves B) Comparison between three sizes of inocula in HEK and in BEK tissue cultures 
indicating that the sensitivity of the test is, for quantitative studies at least, too low. After 72 hrs. however an inoculum containing 0.7 PFU

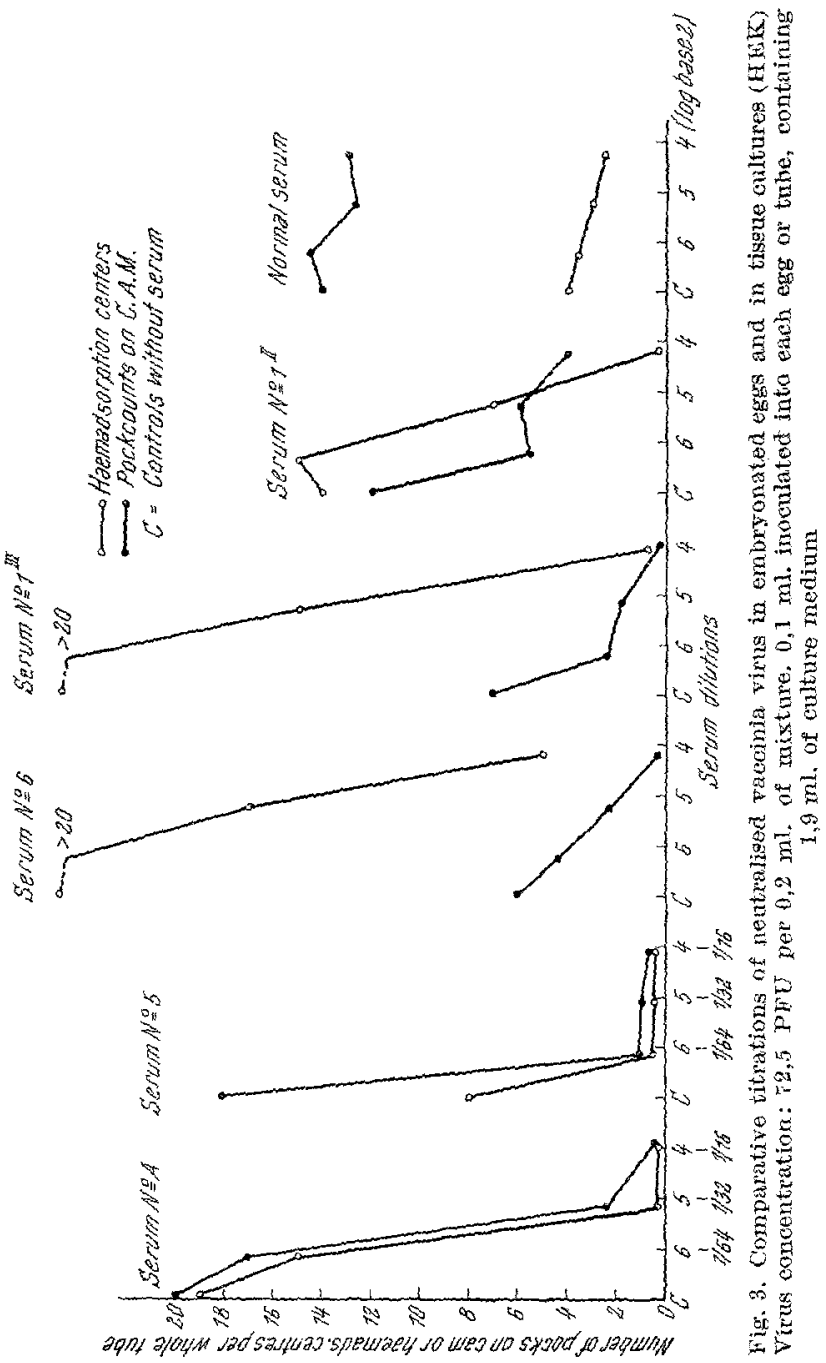

per $2 \mathrm{ml}$. gave about $7-8$ centres per tube, which means about $0.1 \mathrm{PFU}$ for each centre. Although there is the possibility of secondary haemad. sorption centre formation, this small inoeulum was detectable.

d) The sensitivity of the haemadsorption neutralisation test

Comparison of neutralised virus-serum mixtures by means of both haemadsorption centre counts and pock counts (on the chorioallantoic 
membranes of embryonated eggs) indicated that the haemadsorption test gave somewhat higher counts (Fig. 3). This might well be due to

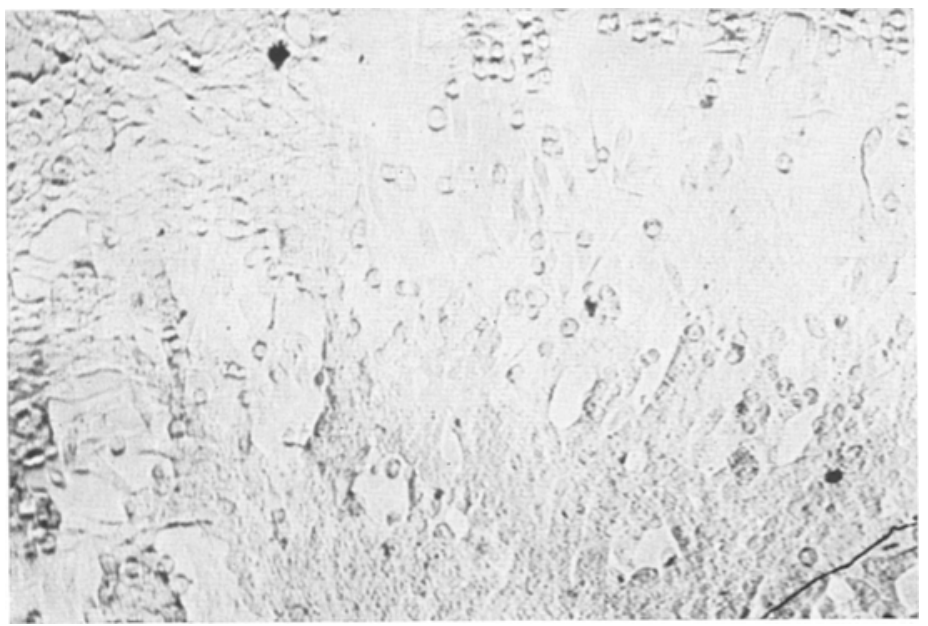

Fig. 4. Normal HEK tissue culture (x 100.) unstained

the formation of secondary centres (48 hrs. incubation period). The haemadsorption neutralisation test was, nevertheless, a sensitive test qualitatively.

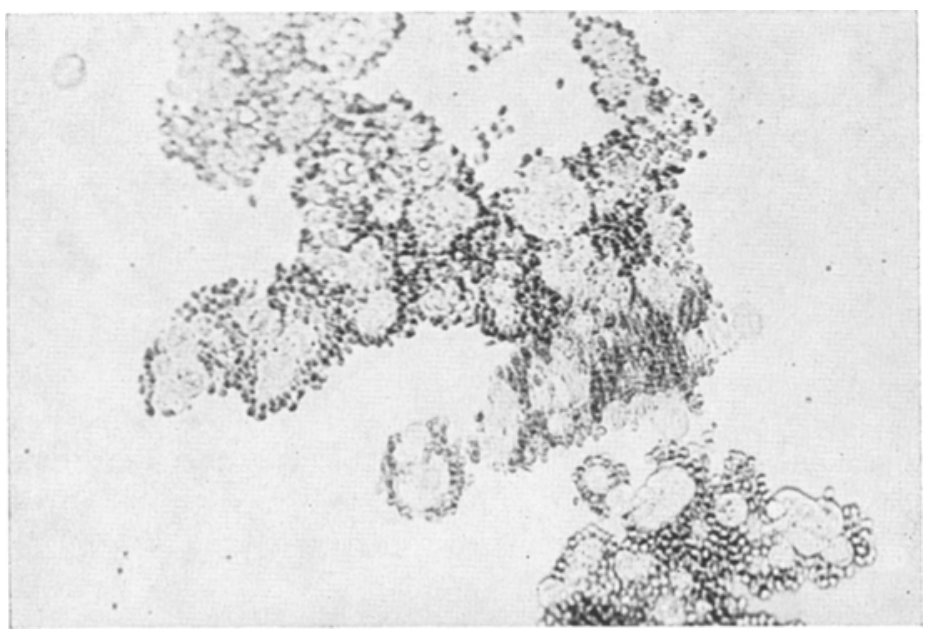

Fig. 5. Haemadsorption. HEK culture $3 \times 24$ hrs. after inoculation

\section{Discussion}

The experimental results showed that haemadsorption tests with vaccinia virus may be carried out in each of the 4 tissue culture systems described and with any fowl erythrocyte sample. The indifference of the 
test to the tissue culture system employed presumably indicated that the production of virus antigens remained unaltered by variation of the host cells, at least in relation to those antigens associated with the haemadsorption of fowl erythrocytes.

Without doubt the most interesting result was that the haemadsorption properties of the vaccinia virus strains to fowl erythrocytes were independent of their haemagglutinating properties. One may presume that either the plate haemagglutination test provides a misleading picture of the sensitivity of fowl erythrocytes to vaccinia haemagglutinins (on the assumption that it is the haemagglutinin which is reponsible for the haemadsorption phenomenon), or that there is an independent haemadsorption factor produced by vaccinia infected tissue culture cells which is capable of reacting with all fowl erythrocytes. Both possibilities must remain open to speculation until further evidence is available.

The specificity of the vaccinia fowl erythrocyte haemadsorption test was shown by the results of the neutralisation tests, and inhibition of the haemadsorption, both carried out with antivaccinia sera and hyperimmune gamma globulin. For qualitative studies with vaccinia virus the neutralisation tests would appear to be both speedy and decisive.

The sensitivity of the tube haemadsorption test for quantitative estimations with vaccinia virus proved to be less than the sensitivity of the chorioallantoic membranes of the embryonated egg. Between 3.0 and $7.2 \times 10^{3} \mathrm{PFU}$ were required in the inoculum for the demonstration of a single haemadsorption centre, within $24 \mathrm{hrs}$. incubation. Most probably this was due to the virus inoculum having been contained in $2.0 \mathrm{ml}$. of culture medium. With the dilution and dispersion of the virus in such a relatively large volume of medium the chance encounters between virus and tissue cells must necessarily involve only part of the total inoculated virus. Therefore haemadsorption centre counts will be low, in relation to the size of the inoculum.

The release of vaccinia virus from infected cells has been shown to commence at about $10 \mathrm{hrs}$. from the time of infection $(6,7)$. For this reason counts made after the $24 \mathrm{hr}$. period might well include secondary haemadsorption centres as well as those centres produced by the original inoculum but delayed in their initiation due to virus dispersion in the medium. Counts did, in fact, increase as the incubation period was extended (Fig. 2). After $72 \mathrm{hrs}$. incubation the test proved to be considerably more sensitive with small sized inocula. An amount of $0.7 \mathrm{PFU}$ per $2 \mathrm{ml}$. gave $7-8$ haemadsorption centres per whole tube. Because of the secondary centre formation mentioned above, this prolonged incubation period was only of value in detecting whether or not there was virus in the inoculum.

From the experimental observations one may conclude that the specificity of the vaccinia fowl erythrocyte haemadsorption test will permit 
its use for qualitative estimations with vacoinia virus. Modification of the test will be required for its use in quantitative estimations.

\section{Summary}

Studies on haemadsorption in vaccinia-infected tube tissue cultures have shown that the reaction was unaltered by variation of the virus strain, tissue culture system or fowl erythrocyte sample. The test described was found to be specific for vaccinia virus but more suitable for qualitative than for quantitative studies with the virus.

\section{Acknowledgements}

We are most grateful to Dr. H.S. Frenkel for providing us with such excellent laboratory facilities.

Our thanks are due, also, to both Dr. S. Frenkel and Dr. J.G. van Bekkum for constant advice, criticism and encouragement.

We are indebted to Dr. B. J. W. Beunders Col. M. D. commander of the Department of Preventive Medicine of the Royal Netherlands Army for making this research possible.

\section{References}

1. Vogel, $J$. and $A$. Shelokov: Adsorption-haemagglutination for influenza virus in monkey kidney tissue culture. Science 126, 358-359 (1957). 2. Shelokov, A., J. E. Voget and Lotta Chi: Haemadsorption (adsorption haemagglutination) test for viral agents in tissue culture with special reference to influenza. Proc. Soc. exp. Biol. Med. 97, 802-809 (1958). - 3. Francis, T.: Editor, Diagnostic procedures for Virus and Rickeltsial Diseases. 2nd ed. P. 116 New York City, American Public Health Association (1956). - 4. Frenkel H. S. and $J$. G. Kapsenberg: The culture of vaccinia virus in explanted foetal bovine and bovine skin tissue. Ned. Tijdschrift voor Geneeskunde 98, No 15, 991-996 (1954). - 5. Kolmer, J. A.: Clinical Diagnosis by Laboratory Examinations. 2nd. ed. P. 438 New York. Appleton-Century Crofts, Inc. (1949). - 6. Orawford, G. N. C. and $F . K$. Sanders: The multiplication of vaccinia virus in tissue cultures of adult rabbit skin. Quart. J. Micr. Sci., 93, 119-132 (1952) 7. Anderson, S. G.: The growth curve of vaccinia virus on the chorioallantois. Aust. J. exp. Biol. med. Sci. 32, $633-639$ (1954). 